SNEŽANA TADIĆ, Ph.D. ${ }^{1}$

E-mail: s.tadic@sf.bg.ac.rs

MILOVAN KOVAČ, M.Sc. ${ }^{1}$

E-mail: m.kovac@sf.bg.ac.rs

OLJA ČOKORILO, Ph.D. ${ }^{1}$

E-mail: o.cokorilo@sf.bg.ac.rs

${ }^{1}$ Faculty of Transport and Traffic Engineering,

University of Belgrade

Vojvode Stepe 305, 11000 Belgrade, Serbia
Transport Logistics Original Scientific Paper Submitted: 30 Sep. 2020 Accepted: 11 Jan. 2021

\title{
THE APPLICATION OF DRONES IN CITY LOGISTICS CONCEPTS
}

\begin{abstract}
With the rise of city logistics (CL) problems in the last three decades, various methods, approaches, solutions, and initiatives were analyzed and proposed for making logistics in urban areas more sustainable. The most analyzed and promising solutions are those that take into account cooperation among logistics providers and consolidation of the flow of goods. Furthermore, technological innovations enable the implementation of modern vehicles/equipment in order to make CL solutions sustainable. For several years, drone-based delivery has attracted lots of attention in scientific research, but there is a serious gap in the literature regarding the application of drones in CL concepts. The goal of this paper is to analyze four $C L$ concepts that differ in consolidation type, transformation degree of flow of goods (direct and indirect, multi-echelon flows), and the role of drones. Two of the analyzed concepts are novel, which is the main contribution of the paper. The performances of the analyzed concepts are compared to the performances of the traditional delivery model - using only trucks without prior flow consolidation. The results indicate that $C L$ concepts which combine different consolidation models and drones in the last phase of the delivery could stand out as a sustainable CL solution.
\end{abstract}

\section{KEYWORDS}

city logistics; CL concept; drone; consolidation; micro-consolidation; multi-echelon system; sustainability.

\section{INTRODUCTION}

Structural changes in the flow of goods, caused by globalization, the growth of e-commerce volumes, demographic changes, emerging technologies and business patterns, etc., are forcing the logistics sector to adapt to the development trends of cities and society in general [1]. Logistics problems in urban areas are directly related to the state and trends of city development [2], while their environmental impact in recent years has become critical.

The rising problems of logistics in urban areas stimulated the growth in interest of scientific research in this field [3]. A vast number of research papers, especially in the last two decades, analyzed various problems, solutions, initiatives, concepts, and approaches in the domain of city logistics (CL). Despite the wide spectre of analyzed CL initiatives and CL concepts, the reason for their practical application absence is inadequate understanding of the nature of the problems and the lack in the analysis of long-term consequences of their application [4].

CL initiatives can be structured according to different criteria, and for this paper, the CL initiatives that refer to cooperation and consolidation of the flow of goods through a logistics center in urban areas are of particular interest. Cooperation and flow consolidation initiatives stand out as a distinct category of the CL solutions [5]. Flow consolidation can be executed through logistics centers outside the delivery area or through city terminals in the delivery zone, in the proximity of the receivers - micro-consolidation.

The emergence of e-commerce and the development of modern information and communication technologies enabled the overcoming of spatial and temporal barriers for markets. The consequence of the abovementioned is the growth in home-delivery demands, the increase of delivery frequency and the reduction of delivery size, the emergence of personalized consumption patterns, and the production of individualized articles [6]. These changes greatly affected the performances of the logistics systems, forcing them to change and adapt. Despite the problems caused by the changes in the nature of supply 
chains, technological innovations enable the application of modern delivery solutions. Unmanned aerial vehicles (drones), as one innovative technology, attracted much attention in the research that covers delivery in urban areas.

This paper analyzes drones in the context of CL concepts. The goal is to analyze the influence of CL concepts (based on the initiatives of cooperation, flow consolidation, and the application of drones in goods delivery) on CL performances. Four CL concepts are analyzed, and their impact on the CL performances is evaluated according to ten test instances. The test instances are generated according to real data regarding the characteristics of the flow (demand) generators. The analyzed concepts are defined according to the existing drone-based delivery variants from the literature, and their combination with the concepts of consolidation and micro-consolidation of the flows of goods. Two of the analyzed CL concepts are novel and this is the main contribution to the scientific literature. The contribution of the paper is also the promotion of the participation of innovative technologies in defining the CL concepts. The performances of the analyzed concepts are compared with the performances of the traditional delivery model using only ground vehicles, without previous flow consolidation. Another contribution of the paper is the consideration of a wider set of the CL performances.

The paper is organized into five sections. The following section presents a short literature review regarding the analysis of the initiatives of cooperation, consolidation, micro-consolidation, and drones in goods delivery. Section 3 describes the CL concepts that are analyzed, as well as the setup of input parameters for their evaluation. The same section describes the way the test instances are generated upon which the analyzed concepts are applied. The results are discussed in section 4, after which the concluding remarks follow.

\section{LITERATURE REVIEW}

The constant need for improvement and adaptation of the logistics to global trends has caused its paradigm shift towards Logistics 4.0. Although the majority of research papers consider Logistics 4.0 to be a revolution mainly in the internal logistics of the individual logistics providers [7], its impact on the CL cannot be neglected. Autonomous vehicles, as one of the emerging technologies of the Logistics 4.0, have given the opportunity for the research to define various new and diverse CL concepts, yet there is no clear prediction of their impact on the future of the CL. Drones, as one of the autonomous technologies, have caused lots of enthusiasm in the existing literature, and are considered a promising technology in the future of goods distribution in urban areas [8].

In theory and practice, diverse CL concepts can be defined. The concepts can differ according to the applied technology, the degree of transformation of the flow of goods, the participants and their role, the comprehensiveness of the flows, application domain, etc. This paper analyzes four CL concepts which are defined as the combination of cooperation, flow consolidation, and drone-based delivery initiatives. The performance of these concepts is compared with the performance of the traditional delivery model - ground vehicle delivery without prior flow consolidation of different logistics providers. The following text presents a short literature overview regarding cooperation and flow consolidation in urban areas as well as different variants of drone-based delivery.

Through the initiatives of cooperation and consolidation, it is possible to improve the efficiency of logistics activities and to reduce the negative environmental impact of logistics. Of course, the effects of cooperation and consolidation are directly dependent on the characteristics of demands, the number of cooperators, spatial dispersion of delivery points, the amount of delivered goods, spatial characteristics of the city, and they are positive only in cases where the economy of scale and adequate planning exist [5].

Different forms of flow consolidation in urban areas are present in the literature. In a physical context, consolidation can be realized through the logistics centers outside the delivery area [9, $10]$, or through city logistics terminals in the close proximity to the receivers $[11,12]$. Flows that pass through logistics centers are transformed from direct to indirect flows [13], therefore the logistics system is transformed into a multi-echelon system, where the echelons (levels) are connected with appropriate logistics facilities (consolidation centers, cross-dock terminals, warehouses, loading/unloading platforms, etc.). The most analyzed and practically applied type of these systems is the 
two-echelon system $[14,15]$, which refers to the realization of flows from the origin to the destination through one intermediate logistics center.

Despite the fact that the application of urban logistics consolidation centers indicates various positive effects on urban sustainability, there is only a limited number of its successful examples of practical application [16]. The sustainability of this initiative category greatly depends on the involvement of the public sector in its financing, planning, realization and, regulation [1, 5, 17].

Flow consolidation through city terminals in the delivery zone is known as micro-consolidation. The goal of micro-consolidation solutions is to reduce the number of commercial vehicle drives in central and densely built city zones by consolidating the flows in the close proximity of the flow generators [11]. The main functions of city terminals are flow consolidation, transhipment, and temporary storage of goods. In micro-consolidation solutions, eco-friendly vehicles (cargo bicycles, light electric vehicles, or even on foot) in the last phase of the delivery are utilized $[11,12,18]$. In accordance with the analysis presented in this paper, the last phase of the delivery can also be realized by drones.

Although drones have been present for several decades, to this day they found their application mostly in military purposes, surveillance, and recreation. In the year 2013, Amazon has shown interest in drone delivery, after which other major companies (DHL, Google, Alibaba, UPS, etc.) began to develop their solutions for drone-based delivery $[19,20]$.

The existing research points out that lower operational costs of drones in comparison with the traditional delivery technologies can make them sustainable and competitive [21]. Likewise, greater movement flexibility and lower negative environmental impact tend to justify this technology for goods delivery. On the other hand, low carrying capacity and limited battery endurance of drones pose the main impediments for their practical application. By combining drones with commercial vehicles, the limited drone carrying capacity is overcome, and the development and application of modular drones enabled their effective usage. The swapping of batteries in modular drones takes only several seconds, and their charging does not require the presence of the drone, as is the case with the models with integrated batteries [22]. Aside from the technical limitations, some authors claim that drone usage could violate safety, privacy, or even endanger some ecosystems [23-25].

The existing research analyzed different dronebased delivery variants. In the first analyzed variant, drone delivery is executed in combination with ground vehicles. During the delivery to a customer, the ground vehicle can release a drone to serve another customer location in the meantime. After serving the customer, the drone returns to its vehicle. This variant attracted lots of attention of researchers due to the combinatorial complexity of the vehicle routing problem with drones. The first authors that attempted to solve the operational problems that follow the application of drones in cooperation with ground vehicles for goods delivery are Murray and Chu [26], and their work was later followed by many research papers on this topic (e.g. [27-29]). Some of the research papers analyzed the variant where a ground vehicle carries multiple drones [30], as well as a heterogeneous vehicle fleet, where some of the ground vehicles are carrying a drone [31].

The second drone-based delivery variant in the existing literature also combines drones with ground vehicles, but in a two-echelon system. In this variant, the ground vehicles serve as mobile logistics centers (depots) and they are allowed only to visit the launching sites. From the launching sites, the allocated customers are served by drones [32]. The drones are allowed to conduct multiple cycles from a location to improve the efficiency of their application. In this variant, the final phase of the delivery is executed exclusively by drones. A relatively limited number of papers analyzed this variant, and some of them analyzed the variant where a ground vehicle carries multiple drones [33], or the ground vehicle carries only one drone that can serve multiple locations in one flight [34]. In the paper [19], the authors analyze a different variant of cooperation between drones and ground vehicles where the purpose of drones is to resupply the ground vehicles during the delivery. The paper [35] analyzed the variant of collaboration between drones and public transportation vehicles in goods delivery.

Besides the aforementioned, there are also variants in which the drones and ground vehicles execute the delivery independently of each other. The drones visit the customer locations directly from the logistics center while the ground vehicles visit 
the locations that are out of the drone flight range, or the amount of goods exceeds the carrying capacity of a drone [36, 37]. Kim and Moon [38] analyzed the variant where the ground vehicles distribute the goods to city terminals that are located close to the customers, from where the delivery is executed by drones. The difference between this approach and the approach in [33] is that the drones and ground vehicles operate independently of each other. In this approach, the drones are bound to city terminals instead of ground vehicles, so after the delivery to a city terminal, the ground vehicle does not have to wait for the drones to complete their delivery. The paper [39] analyzed the concept where the rooftops of city buildings serve as launching sites for delivery drones. The two-echelon approach for goods delivery with drones can provide shorter response times of logistics providers, but would also make the system decentralized and more complex for managing [40].

The existing research that analyzed the application of drones in goods delivery mostly focused on the operational problems (e.g. [20, 26, 27, 29, 38]). Some of the research analyzed the effect of drone application in goods delivery on logistics costs and environmental pollution (e.g. [41, 42]). None of the existing research analyzed the combination of drones with some of the explored CL initiatives. Furthermore, the existing research did not cover a wider set of the CL performances during their analysis of the application of drones in goods delivery in urban areas.

The existing literature mostly analyzed drones as a last-mile transportation mode, rather than as an element of a complex CL concept. This paper analyzes four CL concepts, from which two are novel, that combine different models of flow consolidation with the application of drones. The analyzed concepts differ in the consolidation model, the transformation degree of the flow of goods, and the role of drones. This paper analyzes a concept with direct ground vehicle-drone delivery without prior flow consolidation, two two-echelon concepts that differ in the flow consolidation model, and a three-echelon concept that combines two different consolidation models and the application of drones in the last phase of the delivery. The performances of these concepts is compared to the performances of the traditional delivery model that refers to the direct delivery by ground vehicles only. In the next chapter, the analyzed CL concepts are explained in detail.

\section{CL CONCEPTS FOR DRONE-BASED DELIVERY}

Flow consolidation enables spatial, temporal, and quantitative integration of demands, and as such, stands as one of the ideas that comprises the foundation of the modern understanding of urban logistics. Aside from demand integration, often the secondary goal of consolidation is the application of eco-friendly transportation technologies. Since drones are an eco-friendly transportation technology with significant technical restrictions, the combination of this technology with the initiatives of flow consolidation stands out as a potentially sustainable CL solution. The analyzed CL concepts for drone-based delivery are explained in the following section.

In the first analyzed CL concept (C1), the delivery is realized with the ground vehicle-drone tandem, without prior flow consolidation. In this concept, every ground vehicle carries a drone, and they are synchronized during the delivery. The absence of flow consolidation means that every logistics provider performs the delivery to his customers independently (Figure 1a). This concept is one of the most analyzed in the literature (e.g. [26-31]).

In concept $\mathrm{C} 2$, the delivery of goods is also conducted with the ground vehicle-drone tandem, but with prior flow consolidation in a logistics center (a two-echelon delivery) at the outskirts of the urban area (Figure 1b). In this concept, logistics providers deliver the goods to the logistics center, from where a consolidated delivery is carried out. This concept is an extension of the previous one and is not investigated in the existing literature.

In concept $\mathrm{C} 3$, the micro-consolidation of flows takes place in the close proximity of flow generators. In this concept, logistics providers deliver their goods to city terminals independently, while the final phase of distribution is carried out by drones (Figure 1c). This two-echelon concept uses ground vehicles and drones in different echelons drones independent of ground vehicles. This concept can be found in the existing literature (e.g. $[38,39])$. 


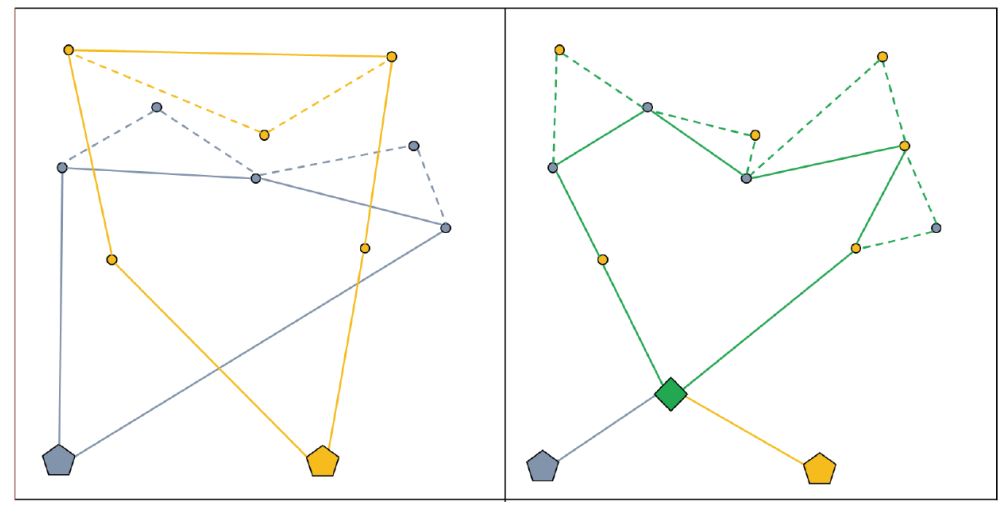

a)

b)

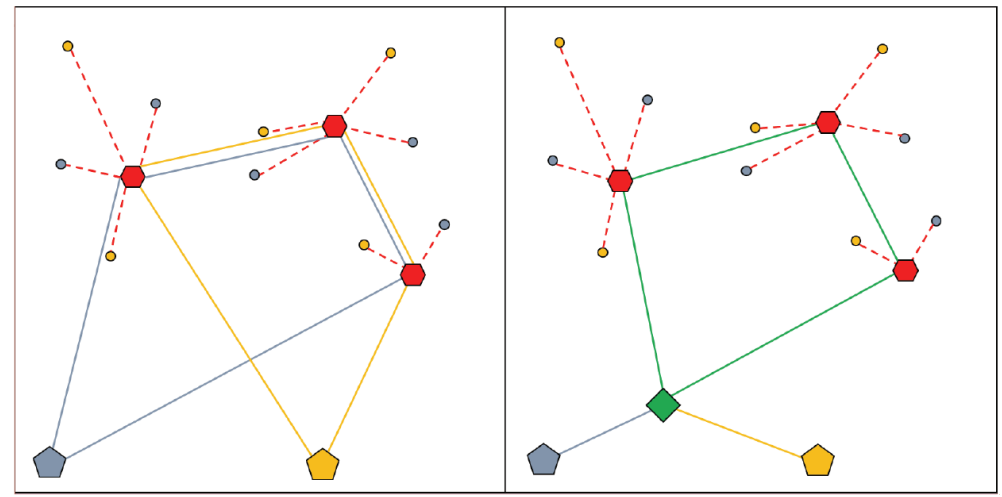

c)

d)

$$
\begin{aligned}
& \text { - } \circ \text { Flow of goods generator (delivery points) - Consolidated ground vehicle route } \\
& \checkmark \text { Logistics centers of individual providers -.- Consolidated drone route } \\
& \text { = Independent routes of ground vehicles - City terminal in the delivery zone } \\
& ==\text { Independent drone routes } \\
& \diamond \text { Logistics center in city outskirts area } \\
& \text {-. Micro-consolidated drone route }
\end{aligned}
$$

Figure 1-Analyzed CL concepts

In concept $\mathrm{C} 4$, the delivery is carried out in a three-echelon manner. In the first echelon, logistics providers deliver the goods to the logistics center in the urban area outskirts. A consolidated delivery is carried out from the logistics center to city terminals inside the delivery zone. After the micro-consolidation of flows, the delivery to the customers is executed with drones (Figure 1d). This is a novel concept and it has not been analyzed in the existing research.

Aside from the described concepts, a traditional delivery model that uses only ground vehicles without flow consolidation $(\mathrm{C} 0)$ is taken into consideration. The performances of the traditional delivery model serves as referent values for the performances of the CL concepts that are analyzed in this paper.

To evaluate the performances of the defined CL concepts, 10 test instances are generated. The dimensions of each instance are 20x20 km, with 1000 flow of goods generators randomly distributed in the defined space. The generators are supplied by 4 logistics providers, while a portion of the generators
Table 1 - Delivery size probability distribution

\begin{tabular}{|c|l|c||}
\hline Delivery size $[\mathrm{kg}]$ & \multicolumn{1}{|c|}{ Delivery size $\left[\mathrm{m}^{3}\right]$} & Probability \\
\hline \hline $\mathrm{U} \sim[0.01 ; 0.5]$ & $\mathrm{U} \sim[0.00001 ; 0.0075]$ & 0.6 \\
\hline $\mathrm{U} \sim[0.5 ; 1]$ & $\mathrm{U} \sim[0.0075 ; 0.02]$ & 0.13 \\
\hline $\mathrm{U} \sim[1 ; 2]$ & $\mathrm{U} \sim[0.02 ; 0.08]$ & 0.08 \\
\hline $\mathrm{U} \sim[2 ; 5]$ & $\mathrm{U} \sim[0.08 ; 0.1]$ & 0.09 \\
\hline $\mathrm{U} \sim[5 ; 10]$ & $\mathrm{U} \sim[0.1 ; 0.3]$ & 0.05 \\
\hline $\mathrm{U} \sim[10 ; 20]$ & $\mathrm{U} \sim[0.3 ; 0.5]$ & 0.03 \\
\hline $\mathrm{U} \sim[20 ; 25]$ & $\mathrm{U} \sim[0.5 ; 1]$ & 0.02 \\
\hline
\end{tabular}

is supplied by more than one logistics provider. Every generator has randomly assigned providers, where $75 \%$ of generators are supplied only by one provider, $20 \%$ of generators are supplied by two providers, while the remaining $5 \%$ is supplied by 3 providers. Logistics providers are located on the edge of the defined area. The delivery size is defined according to the probability distribution (Table 1). All probability distributions in this paper are based on 
empirical data of multiple logistics providers collected in a case study of CL parameters in the city of Belgrade for the year 2019.

In addition to the delivery size, a time window during which the deliveries have to be carried out is assigned to every generator according to a discrete probability distribution (Table 2).

Table 2 - Demanded delivery time intervals probability distribution

\begin{tabular}{||c|c|c||}
\hline Time window & Time window span & Probability \\
\hline \hline $9: 00-11: 00 \mathrm{~h}$ & $2 \mathrm{~h}(7200 \mathrm{~s})$ & 0.5 \\
\hline $11: 00-12: 00 \mathrm{~h}$ & $1 \mathrm{~h}(3600 \mathrm{~s})$ & 0.35 \\
\hline $12: 00-15: 00 \mathrm{~h}$ & $3 \mathrm{~h}(10800 \mathrm{~s})$ & 0.15 \\
\hline
\end{tabular}

It is assumed that the vehicle park is homogeneous, and is comprised of small commercial vehicles with the carrying capacity of $850 \mathrm{~kg}$ and the loading space volume of $4 \mathrm{~m}^{3}$. Every logistics provider's working hours begin at 7:00 AM, and the maximum allowed working hours of the drivers is 8 hours. The structure of the drone vehicle park is also homogeneous, and it is assumed that the carrying capacity of a drone is $3 \mathrm{~kg}$, while the maximal duration of a drone flight is 40 minutes. It is assumed that the average driving speed of ground vehicles is $30 \mathrm{~km} / \mathrm{h}$, and of drones $55 \mathrm{~km} / \mathrm{h}$. Drone performances are generalized so that they would fit into the third class in the national categorization of unmanned aerial vehicles in Serbia [43]. It should be pointed out that the parcels that exceed the capacity of drones are delivered by ground vehicles regardless of the CL concept.

Various CL performances and indicators for the analysis of the impact of the CL concepts on urban sustainability can be defined [44]. The existing research took into consideration only a narrow set of CL performances during their analysis of dronebased delivery. This mostly referred to costs [33], environmental pollution [41], costs and environmental pollution [42], costs and distance travelled [31], etc. This paper takes into consideration a wider set of CL performances: delivery costs, distance travelled by vehicles, $\mathrm{CO}_{2}$ emissions, overall delivery completion times, number of vehicle trips, and the degree of loading space utilization in ground vehicles.

Delivery costs are comprised of the trip costs, that is, the costs of the distance travelled by ground vehicles and drones, vehicle driver labour costs, and all costs regarding the delivery processing (transhipment, sorting, consolidation, packing, marking, etc.) in the concepts with the flow consolidation at the logistics centers. All costs are based upon empirical data, while it is assumed that the travelling costs of drones are approximately 25 times lower than the costs of ground vehicles [28].

The distances travelled by ground vehicles and drones are measured as the sum of all route lengths that are the result of operational planning in the analyzed CL concepts. It is the simplest CL performance to measure and understand, and therefore one of the most analyzed in the literature and practice.

The emission of air pollutants depends on the technical characteristics of vehicles, travelled distance, road infrastructure, number of vehicle stops, the amount of cargo the vehicles are transporting, etc. In this paper, the ground vehicle $\mathrm{CO}_{2}$ emissions $\left(E^{\text {truck }}\right)$ on its route $(L)$ are calculated as the sum of the emissions on all segments of the route [45]:

$E^{\text {truck }}=\sum_{i=1}^{L} l_{i} \cdot\left(E^{\text {empty }}+\left(E^{\text {full }}-E^{\text {empty }}\right) \cdot \alpha_{i}\right)$

where $l_{i}$ represents the distance that the vehicle travels on the segment $i, \alpha_{i}$ stands for the ratio of goods volume in the vehicle and its loading space volume on the route segment $i, E^{\text {empty }}$ are the $\mathrm{CO}_{2}$ emissions of the empty vehicle, $E^{\text {full }}$ are the $\mathrm{CO}_{2}$ emissions of the full vehicle. Besides the fact that one of the advantages in the application of drones is the absence of air pollutant emissions, it is important to take into consideration the air pollutant emissions that are released in the process of electric power generation needed for powering the drone batteries. According to [41], the emission of $\mathrm{CO}_{2}$ that is created during the electric power generation for drones is 0.3773 $\mathrm{kg} \mathrm{CO}_{2} / \mathrm{kWh}$, where the average drone energy consumption is $100 \mathrm{Wh} / \mathrm{km}$. Having this in mind, drone emissions are approximated to be $37.73 \mathrm{~g} \mathrm{CO}_{2} / \mathrm{km}$. All input parameters relevant for the analysis of the CL performances of the defined CL concepts are presented in Table 3.

Overall delivery completion time is comprised of the travelling times of ground vehicles and drones, the duration of transhipment (loading and unloading) in logistics centers, the time needed for flow consolidation and the customer serving time (searching for parking, unloading of goods, transfer of goods, payment, etc.), and it represents the time needed for the completion of all deliveries. In other words, it represents the labour duration of 
Tadić S, Kovač M, Čokorilo O. The Application of Drones in City Logistics Concepts

Table 3 - Input parameter values for the analyzed CL concepts

\begin{tabular}{||l|c|c||}
\hline \multicolumn{1}{|c|}{ Input parameter } & Dimension & Source \\
\hline \hline Carrying capacity of commercial vehicles & $850 \mathrm{~kg}$ & empirical \\
\hline Loading space volume of commercial vehicles & $4 \mathrm{~m} 3$ & empirical \\
\hline Drone carrying capacity & $3 \mathrm{~kg}$ & empirical \\
\hline Average traveling speed of commercial vehicles & $30 \mathrm{~km} / \mathrm{h}(8.33 \mathrm{~m} / \mathrm{s})$ & {$[43]$} \\
\hline Average traveling speed of drones & $55 \mathrm{~km} / \mathrm{h}(15.28 \mathrm{~m} / \mathrm{s})$ & {$[43]$} \\
\hline Drone flight endurance & $40 \mathrm{~min}(2400 \mathrm{~s})$ & empirical \\
\hline Customer serving time by commercial vehicles & $10 \mathrm{~min}(600 \mathrm{~s})$ & generalized \\
\hline Customer serving time by drones & $1.5 \mathrm{~min}(90 \mathrm{~s})$ & empirical \\
\hline Distance costs of commercial vehicles & $0.6 € / \mathrm{km}$ & empirical \\
\hline Labor costs & $2.2 € / \mathrm{h}$ & {$[28]$} \\
\hline Distance costs of drones & $0.009 € / \mathrm{km}$ & {$[46]$} \\
\hline $\mathrm{CO}_{2}$ emissions of empty commercial vehicles & $228 \mathrm{~g} \mathrm{CO}_{2} / \mathrm{km}$ & {$[46]$} \\
\hline $\mathrm{CO}_{2}$ emissions of full commercial vehicles & $305 \mathrm{~g} \mathrm{CCO}_{2} / \mathrm{km}$ & {$[46]$} \\
\hline $\mathrm{CO}_{2}$ emissions of drones & $37.73 \mathrm{~g} \mathrm{CO}_{2} / \mathrm{km}$ & \\
\hline \hline
\end{tabular}

vehicles that is required to complete all deliveries. It is calculated as the sum of all individual delivery completion times of vehicles.

Besides the travelled distance, the number of vehicle trips is one of the simpler CL performances to understand. It is equal to the number of planned routes required to complete all deliveries. The loading space utilization in ground vehicles $(L S U)$ represents the ratio of the overall volume of goods loaded into a vehicle on one delivery trip and its loading space volume, and it can be calculated as follows:

$$
L S U=\sum_{j=1}^{J} \frac{q_{j}}{Q^{t r u c k}}
$$

where $j$ represents the location that the vehicle visits on the tour $J$ with the delivery demand volume $q_{j} \cdot Q^{\text {truck }}$ represents the loading space volume of the ground vehicle.

The average value of all CL performances per delivery is determined by dividing their overall value with the overall number of deliveries.

In order to conduct the analysis, the following methodology is applied. In the first step, the test instances are generated according to the empirical data. In the second step, all relevant problems on

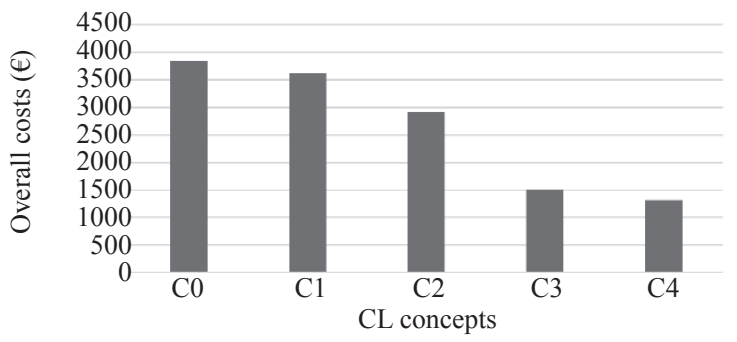

a) Overall tactical (location and number of city terminals [32, $38,39]$ ) and operational (consequent routing and scheduling problems $[15,20,26,27,30,31])$ levels that follow the implementation of the observed CL concepts are solved according to the existing literature and the authors' experience. In the final step, the CL performances are derived from the obtained solutions. The analysis of the results is presented in the next section.

\section{RESULT ANALYSIS}

The results analysis indicates that the overall delivery costs could be significantly reduced in some concepts that apply the drone technology in goods delivery. In the $\mathrm{C} 1$ concept, the delivery cost savings are 5\% in comparison with the traditional delivery model $\mathrm{C} 0$, while the concepts that combine the application of drones with flow consolidation achieve significant cost savings (Figure $2 a$ ). In the $\mathrm{C} 4$ concept, it is possible to achieve $65 \%$ cost savings in comparison with the traditional delivery model. In other words, it is possible to reduce the average delivery cost from almost $€ 3$ down to $€ 1$ per delivery (Figure $2 b$ ).

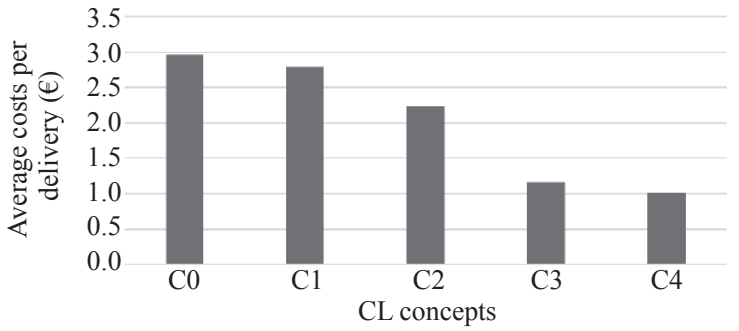

b) Average per delivery

Figure 2 - Delivery costs 
The distance travelled by ground vehicles is reduced in all concepts on the account of the increment of the distance travelled by drones, but also due to flow consolidation (Figure 3). In the concepts with logistics centers on the outskirts of urban areas (C2 and C4), significant savings in distance travelled by ground vehicles and drones are achieved. The concepts with micro-consolidation (C3 and $\mathrm{C} 4)$ tend to lead to a greater utilization of drones which leads to further reduction of the distance travelled by ground vehicles, but also to the increment of the distance travelled by drones. The concept that reduces the ground vehicle distance travelled the most is $\mathrm{C} 4$. The highest distance travelled by drones is achieved by the $\mathrm{C} 3$ concept, followed by the $\mathrm{C} 4$ concept.

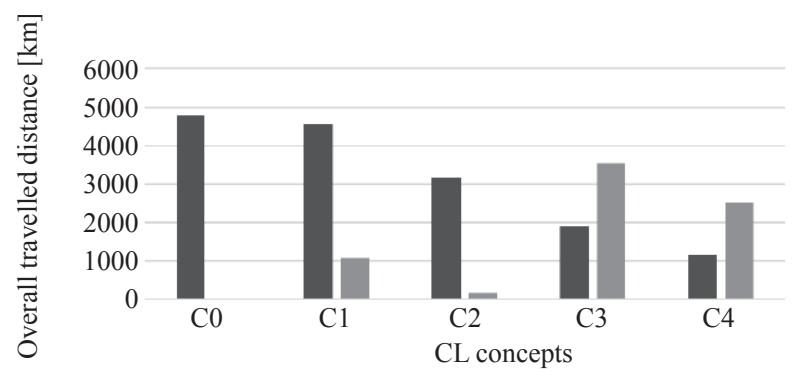

a) Overall
As expected, the analyzed CL concepts cause the reduction of ground vehicle trips on a daily basis. In the $\mathrm{C} 1$ concept, the reduction is negligible compared with the concepts that apply flow consolidation (Figure 4). The $\mathrm{C} 3$ and $\mathrm{C} 4$ concepts achieve the greatest reduction of ground vehicle trips (Figure 4a), but these concepts shift the last-mile delivery on the drone technology, which is followed by the increment of drone trips on a daily basis (Figure $4 b$ ).

As with the travelled distance, the reduction of air-pollutants is significant in the $\mathrm{C} 2, \mathrm{C} 3$, and C4 concepts (Figure 5). The consolidation and micro-consolidation of flows, with the application of drones in the last phase of deliveries (C4 concept), achieves the greatest reduction in $\mathrm{CO}_{2}$ emissions (65\% compared to the traditional delivery model).

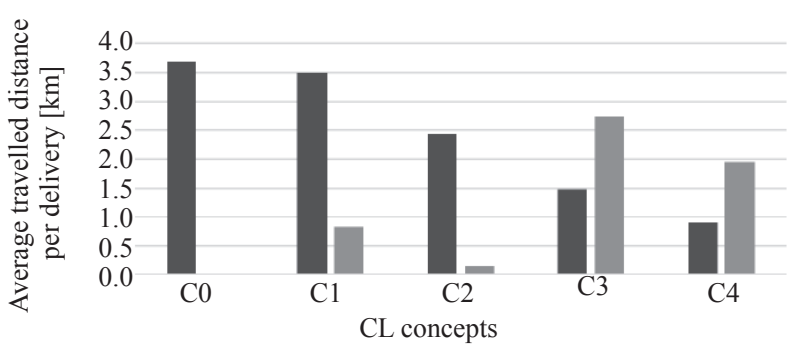

b) Average per delivery

Ground vehicles Drones

Figure 3 - Distance travelled

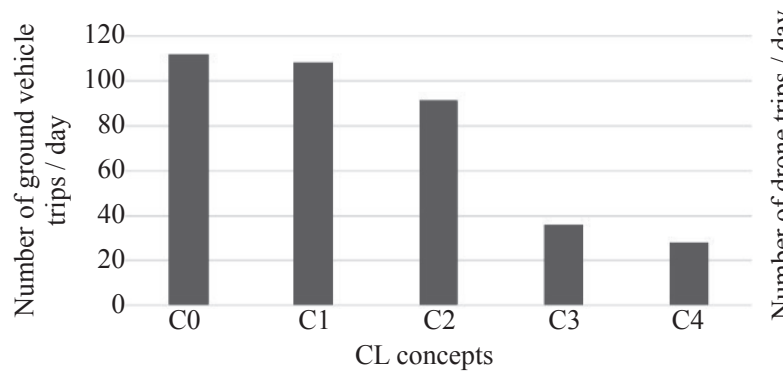

a) Ground vehicles / day

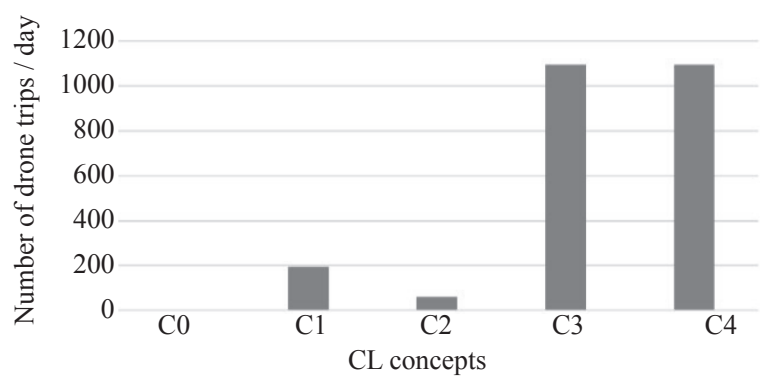

b) Drones / day

Figure 4-Number of vehicle trips

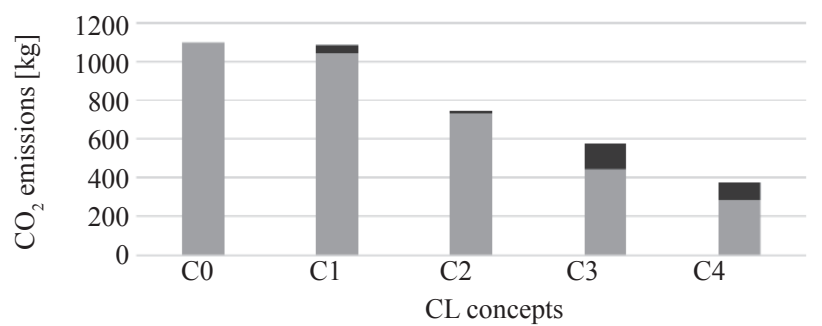

a) Overall

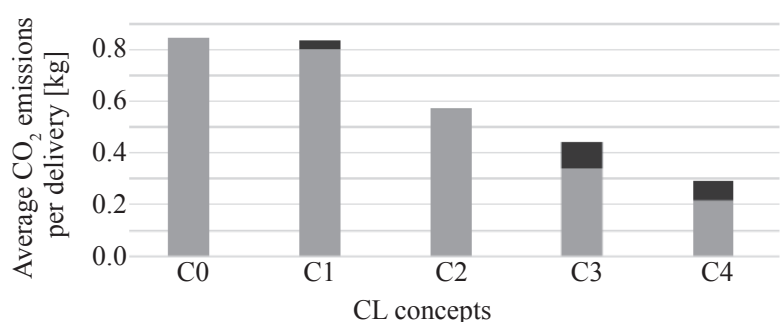

b) Delivery average

Ground vehicles Drones

Figure 5-CO2 emissions 


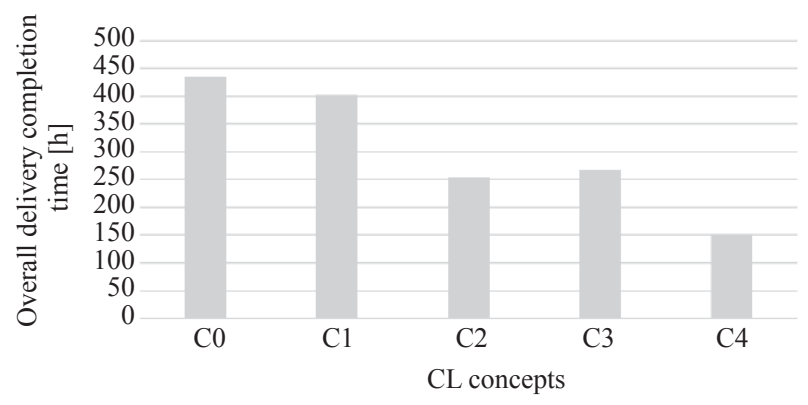

a) Overall

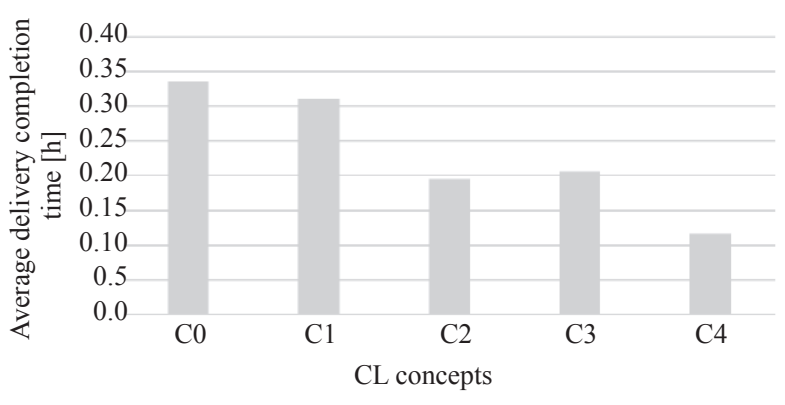

b) Delivery average

Ground vehicles Drones

Figure 6-Delivery completion time

The overall delivery completion times are drastically reduced in the $\mathrm{C} 2, \mathrm{C} 3$, and $\mathrm{C} 4$ concepts (Figure 6a), where the average delivery completion time of 20 minutes (traditional delivery model $\mathrm{C} 0$ ) is reduced to 7 minutes in the $\mathrm{C} 4$ concept (Figure 6b). Significant reduction of delivery completion time in the $\mathrm{C} 4$ concept is the result of combining two different flow consolidation concepts, but also due to the independent utilization of drones in relation to the ground vehicles.

The utilization of vehicle loading space is an important indicator of delivery efficiency. The rising involvement of precise time-defined deliveries has a huge impact on the reduction of vehicle loading space utilization. The average loading space utilization degree in the traditional delivery model is only $15 \%$, while this degree rises in the concepts that apply flow consolidations (Figure 7). The results indicate that the application of micro-consolidation and drones in the last phase of the delivery (C3 and $\mathrm{C} 4$ concepts) can drastically mitigate the negative impacts of time windows on logistics activity efficiency - in this case, the ground vehicle loading space utilization degree. It should be pointed out that the configuration of test instances and input parameters (average customer serving time, limited working

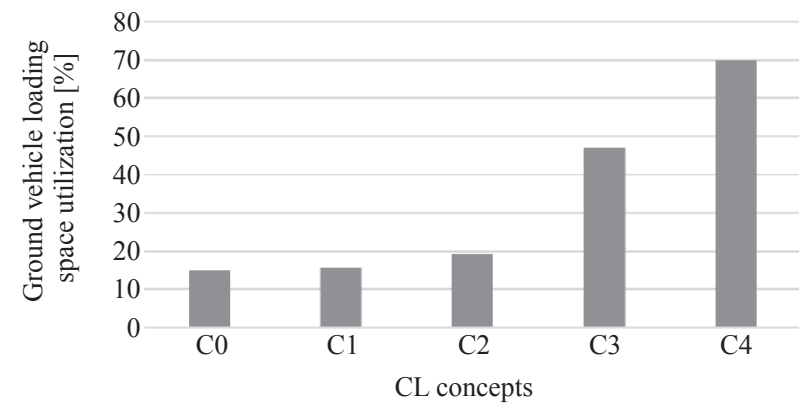

Figure 7 - The utilization degree of ground vehicle loading space hours of ground vehicles, the probability distribution of delivery volume, etc.) have also greatly affected the ground vehicle loading space utilization degree.

The presented analysis of the results shows that the application of drones in goods distribution can have significant effects on sustainability. Drone application effects greatly depend on the CL concept. The effects of the $\mathrm{C} 1$ concept are almost negligible, which is primarily the consequence of the fact that the ground vehicles are carrying only one drone. The research that analyzes the concepts where the ground vehicles are carrying more than one drone exists [33], but the practical feasibility of such approaches remains questionable. The effects of the ground vehicle-drone tandem delivery are significant in the concept with prior flow consolidation (C2). The result analysis indicates that the concepts that combine drone-based delivery with micro-consolidation of the flow of goods in the close proximity of flow generators (C3 and $\mathrm{C} 4)$ have significant positive effects on urban sustainability. The concepts $\mathrm{C} 3$ and $\mathrm{C} 4$ drastically reduce overall logistics costs, the number of ground vehicle trips, air-pollutant emissions, and overall delivery completion time. On the other hand, the concepts $\mathrm{C} 3$ and $\mathrm{C} 4$ make the delivery process more complex by transforming it into a two-echelon ( $\mathrm{C} 3$ concept) and a three-echelon ( $\mathrm{C} 4$ concept) system. The $\mathrm{C} 4$ concept stands out as the best one because it combines the concepts of flow consolidation on the outskirts of the urban area and micro-consolidation in the close proximity of flow generators as well. Such an approach reduces the negative effects that specific demand characteristics (in this case heterogeneous time-windows) have on the efficiency of the logistics activities. 
The micro-consolidation of flows has shifted the delivery core on the drone technology, which results in a large number of drone flights in the central city zone and opens various questions on this topic. The problems that would follow the implementation of concepts $\mathrm{C} 3$ and $\mathrm{C} 4$ are of tactical and operational nature, and they refer to the estimation of the number and locations of city terminals and the number of drones in each terminal. Furthermore, the implementation of any drone-based CL concept must be followed by appropriate regulations, which has not been the case so far.

\section{CONCLUSIONS}

This paper analyzed four different CL concepts that combine different flow consolidation models and drone-based delivery. Two concepts are based on the existing ideas in the literature, while the remaining two concepts are novel and are defined as their extensions by introducing flow consolidation at the outskirts of urban areas, which is the main contribution of this paper. Other contributions of the paper are considering a wider set of CL performances and exploring innovative technologies in the $\mathrm{CL}$ concepts that require more attention in the literature. The results indicate that the combination of flow consolidation on the outskirts of urban areas, micro-consolidation in the close proximity of flow generators, and the application of drones in the last phase of delivery could reduce the negative effects of specific flow generator (customers) demands on logistics sustainability in cities. Despite the promising results, especially in the concepts with micro-consolidation, it is necessary to further analyze and examine their practical applicability. The application of drones in last-mile delivery, but also the implementation of multi-echelon CL concepts, opens a wide variety of questions on all planning levels. With trends such as the growing e-commerce volumes and events such as the ongoing pandemic that affect consumption patterns at a global level, new challenges are set upon the logistics sector and complex CL concepts gain on significance.

The limitation of this research is having its focus only on the effects of the implementation of the CL concepts. Additional research should be conducted in analyzing the required investments and public-private partnership models for the development of such solutions. A proper financial risk assessment for all involved participants is essential. Another limitation of this paper is in observing the concepts in a static environment. The direction of future research should primarily be focused on the analysis of the examined CL concepts in a real-case dynamic and stochastic environment. Aside from the observed performances, it would be interesting to analyze the flexibility and reliability of logistics systems with applied drones in the delivery process. Furthermore, every concept is specific in its way and requires solving various problems on a tactical and operational level, especially the more complex concepts with flow consolidation. A very narrow set of literature papers focused on the dimensioning problems in complex CL concepts, which in this case refers to the required number of city terminals, drones, drone batteries, ground vehicle fleet size, etc. Having in mind that the size and battery endurance of the drones are rather difficult to achieve in real-life, the assumptions in this paper are taken for calculation purposes.

Future research could focus on the development of models for solving the planning problems that follow the implementation of complex drone-based CL concepts. Lastly, future research should include other drone-based delivery variants and their combination with different $\mathrm{CL}$ initiatives and concepts.

Special attention should be given to legislative aspects of the implementation of drone-based delivery concepts. Issues in this area that require attention refer to the provision of public space for the development of consolidation centers at the urban areas, and the access permission for drones in the urban air space. Poorly developed regulative frameworks can pose serious impediments for the development of promising CL concepts.

SNEŽANA TADIĆ, Ph.D. ${ }^{1}$

E-mail: s.tadic@sf.bg.ac.rs

MILOVAN KOVAČ, M.Sc. ${ }^{1}$

E-mail:m.kovac@sf.bg.ac.rs

OLJA ČOKORILO, Ph.D. ${ }^{1}$

E-mail: o.cokorilo@sf.bg.ac.rs

${ }^{1}$ Saobraćajni fakultet, Univerzitet u Beogradu

Vojvode Stepe 305, 11000 Beograd, Srbija

\section{PRIMENA DRONOVA U KONCEPCIJAMA CITY LOGISTIKE}

\section{REZIME}

Sa porastom problema city logistike (CL) u poslednje tri decenije, različite metode, pristupi, rešenja i inicijative su bili analizirani i predloženi kako bi učinili logistiku u urbanim sredinama održivom. Najčešće analizirana rešenja, koja nagoveštavaju uspeh, su ona koja u obzir 
uzimaju kooperaciju logističkih provajdera $i$ konsolidaciju robnih tokova. Osim toga, tehnološke inovacije omogućavaju primenu savremenih vozila/opreme kako bi rešenja CL dostigla održivost. Već nekoliko godina unazad je isporuka robe dronovima privukla dosta pažnje u naučnim istraživanjima međutim, postoji ozbiljan nedostatak u literaturi koji se tiče analize primene dronova u koncepcijama CL. Cilj ovog rada je analiza četiri CL koncepcije koje se razlikuju prema tipu konsolidacije, stepenu transformacije robnih tokova (direktni i indirektni, višeešalonski tokovi), i ulozi dronova. Dve analizirane koncepcije su nove, što predstavlja glavni doprinos rada. Performanse analiziranih koncepcija su poređene sa performansama tradicionalnog modela isporuke - primenom drumskih dostavnih vozila bez prethodne konsolidacije tokova. Rezultati ukazuju na to da CL koncepcije koje kombinuju različite tipove konsolidacije $i$ dronove $u$ poslednjoj fazi isporuke mogu predstavljati održivo CL rešenje.

\section{KLJUČNE REČI}

city logistika; CL koncepcija; dron; konsolidacija; mikro-konsolidacija; višeešalonski sistem; održivost.

\section{REFERENCES}

[1] Tadić S, Zečević S. Modeliranje koncepcija city logistike. Faculty of Transport and Traffic Engineering, University of Belgrade, Belgrade, Serbia; 2016. Serbian.

[2] Tadić S, Zečević S, Krstić M. City logistics - status and trends. International Journal for Traffic and Transport Engineering. 2015;5(3): 319-343. DOI: 10.7708/ ijtte.2015.5(3).09

[3] Rezende Amaral R, Šemanjski I, Gautama S, Aghezzaf E-H. Urban mobility and city logistics - Trends and case study. Promet - Traffic\&Transportation. 2018;30(5): 613-622. DOI: 10.7307/ptt.v30i5.2825

[4] Van Rooijen T, Guikink D, Quak H. Long-term effects of innovative city logistics measures. In: Taniguchi E, Thompson RG. (eds.) City Logistics 1: New Opportunities and Challenges. 1st ed. Hoboken, New Jersey: John Wiley \& Sons; 2018. p. 189-208. DOI: 10.1002/9781119425519.ch10

[5] Tadić S, Zečević S. Kooperacija i konsolidacija tokova u city logistici. Tehnika. 2015;62(4): 687-694. Serbian. DOI: $10.5937 /$ tehnika1504687T

[6] Tadić S, Zečević S, Petrović-Vujačić J. Globalni trendovi i razvoj logistike. Ekonomski vidici. 2013;18(4): 519-532. Serbian. Available from: http://www.deb.org.rs/wp-content/uploads/2015/05/Ekonomski-vidici-04_2013.pdf

[7] Kostrzewski M, Varjan P, Gnap J. Solutions dedicated to internal Logistics 4.0. In: Grzybowska K, Awasthi A, Sawney R. (eds.) Sustainable logistics and production in Industry 4.0. Springer, Switzerland; 2020. p. 243-262. DOI: $10.1007 / 978-3-030-33369-0$

[8] Aurambout J-P, Gkoumas K, Ciuffo B. Last mile delivery by drones: an estimation of viable market potential and access to citizens across European cities. European Transport Research Review. 2019;11(1): 30. DOI: 10.1186/s12544-019-0368-2

[9] Raicu S, Costescu D, Burciu S. Distribution system with flow consolidation at the boundary of urban congested areas. Sustainability. 2020;12(3): 990-1007. DOI: 10.3390/su12030990

[10] Allen J, Browne M, Woodburn A, Leonardi J. The role of urban consolidation centres in sustainable freight transport. Transport Reviews. 2012;32(4): 473-490. DOI: 10.1080/01441647.2012.688074

[11] Janjevic M, Ndiaye AB. Development and application of a transferability framework for micro-consolidation schemes in urban freight transport. Procedia - Social and Behavioral Sciences. 2014;125: 284-296. DOI: 10.1016/j.sbspro.2014.01.1474

[12] Rai HB, Verlinde S, Macharis C. City logistics in an omnichannel environment: The case of Brussels. Case Studies on Transport Policy. 2019;7: 310-317. DOI: 10.1016/j.cstp.2019.02.002

[13] Dondo R, Mendez C, Cerda J. The multi-echelon vehicle routing problem with cross dock in supply chain management. Computers \& Chemical Engineering. 2011;35(12): 3002-3024. DOI: 10.1016/j.compchemeng.2011.03.028

[14] Cuda R, Guastaroba G, Speranza MG. A survey on two-echelon routing problems. Computers \& Operations Research. 2015;55: 185-199. DOI: 10.1016/j. cor.2014.06.008

[15] Yang P, Zeng L. Models and methods for two-echelon location routing problem with time constraints in city logistics. Mathematical Problems in Engineering. 2018: 1-9. DOI: $10.1155 / 2018 / 2549713$

[16] Vahrenkamp R. 25 years city logistic: Why failed the urban consolidation centres? European Transport. 2016;60(4): 1-6.

[17] Akgun Z, Monios J, Fonzone A. Supporting urban consolidation centres with urban freight transport policies: A comparative study of Scotland and Sweeden. International Journal of Logistics Research and Applications. 2019;23(3): 291-310. DOI: 10.1080/ 13675567.2019.1679743

[18] Browne M, Allen J, Leonardi J. Evaluating the use of an urban consolidation centre and electric vehicles in central London. IATSS Research. 2011;35(1): 1-6. DOI: 10.1016/j.iatssr.2011.06.002

[19] Dayarian I, Savelsbergh M, Clarke J-P. Same-day delivery with drone resupply. Transportation Science. 2020. DOI: $10.1287 /$ trsc. 2019.0944

[20] Dorling K, Heinrichs J, Messier G, Magierowski S. Vehicle routing problems for drone delivery. IEEE Transactions on Systems, Man, and Cybernetics: Systems. 2017;47(1): 70-85. DOI: 10.1109/TSMC.2016.2582745

[21] Tavana M, Khalili-Damghani K, Santos-Artega F, Zandi M. Drone shipping versus truck delivery in a cross-docking system with multiple fleets and products. Expert Systems with Applications. 2017;72:93-107. DOI: 10.1016/j. eswa.2016.12.014

[22] Lee J. Optimization of a modular drone delivery system, In: 2017 Annual IEEE International Systems Conference (SysCon), April 2017, Montreal, Quebec; 2017. p. 1-8. DOI: 10.1109/SYSCON.2017.7934790

[23] Rao B, Gopi AG, Maione R. The societal impact of commercial drones. Technology in Society. 2016;45: 83- 
90. DOI: 10.1016/j.techsoc.2016.02.009

[24] Stocker C, Bennett R, Nex F, Gerke M, Zevenbergen J. Review of the current state of UAV regulations. Remote Sensing. 2017;9(5): 495-520. DOI: 10.3390/rs9050459

[25] Čokorilo O, Miščević M. Civil drones: Safety issues. In: Proceedings of the International Symposium: Strategical Transport Development in Southeast Europe, 2018, Budva, Montenegro; 2018. p. 107-113.

[26] Murray C, Chu A. The flying sidekick traveling salesman problem: Optimization of drone-assisted parcel delivery. Transportation Research Part C: Emerging Technologies. 2015;54: 86-109. DOI: 10.1016/j.trc.2015.03.005

[27] Agatz N, Bouman P, Schmidt M. Optimization approaches for the traveling salesman problem with drone. Transportation Science. 2018;52(4): 965-981. DOI: 10.1287/ trsc.2017.0791

[28] Ha Q, Deville Y, Pham Q, Ha M. On the min-cost traveling salesman problem with drone. Transportation Research Part C: Emerging Technologies. 2018;86: $597-$ 621. DOI: 10.1016/j.trc.2017.11.015

[29] Es Yurek E, Ozmutlu H. A decomposition-based iterative optimization algorithm for traveling salesman problem with drone. Transportation Research Part C: Emerging Technologies. 2018;91: 249-262. DOI: 10.1016/j. trc.2018.04.009

[30] Schermer D, Moeini M, Wendt O. A metaheuristic for the vehicle routing problem with drones and its variants. Transportation Research Part C: Emerging Technologies. 2019;106: 166-204. DOI: 10.1016/j.trc.2019.06.016

[31] Popović D, Kovač M, Bjelić N. A MIQP model for solving the vehicle routing problem with drones. In: Proceedings of $4^{\text {th }}$ Logistics International Conference - LOGIC, May 2019, Belgrade, Serbia; 2019. p. 52-62.

[32] Mourelo Ferrandez S, Harbison T, Weber T, Sturges R, Rich R. Optimization of a truck-drone in tandem delivery network using k-means and genetic algorithm. Journal of Industrial Engineering and Management. 2016;9(2): 374-388. DOI: 10.3926/jiem.1929

[33] Karak A, Abdelghany K. The hybrid vehicle-drone routing problem for pick-up and delivery services. Transportation Research Part C: Emerging Technologies. 2019;102: 427-449. DOI: 10.1016/j.trc.2019.03.021

[34] Luo Z, Liu Z, Shi J. A two-echelon cooperated routing problem for a ground vehicle and its carried unmanned aerial vehicle. Sensors. 2017;17(5): 1144-1161. DOI: 10.3390/s17051144

[35] Huang H, Savkin AV, Huang C. Scheduling of a parcel delivery system consisting of an aerial drone interacting with public transportation vehicles. Sensors. 2020;20(7): 2045-2062. DOI: 10.3390/s20072045

[36] Dell'Amico M, Montemanni R, Novellani S. Metaheuristic algorithms for the parallel drone scheduling traveling salesman problem. Annals of Operations Research. 2020: 1-16.

[37] Mbiadou Saleu R, Deroussi L, Feillet D, Grangeon N, Quilliot A. An iterative two-step heuristic for the parallel drone scheduling traveling salesman problem. Networks. 2018;72(2): 459-474. DOI: 10.1002/net.21846

[38] Kim S, Moon I. Traveling salesman problem with a drone station. IEEE Transactions on Systems, Man and Cybernetics: Systems. 2018;99: 1-11. DOI: 10.1109/ TSMC.2018.2867496

[39] Kim J, Moon H, Jung H. Drone-based parcel delivery using rooftops of city buildings: Model and solution. Applied Sciences. 2020;10(12): 4362-4381. DOI: 10.3390/ app10124362

[40] Perera S, Dawande M, Janakiraman G, Mookerjee V. Retail deliveries by drones: How will logistics networks change. Production and Operations Management. 2020 (Accepted manuscript). DOI: 10.1111/poms.13217

[41] Goodchild A, Toy J. Delivery by drone: An evaluation of unmanned aerial vehicle technology in reducin $\mathrm{CO}_{2}$ emissions in the delivery service industry. Transportation Research Part D: Transport and Environment. 2018;61: 58-67. DOI: 10.1016/j.trd.2017.02.017

[42] Chiang W-C, Li Y, Shang J, Urban T. Impact of drone delivery on sustainability and cost: Realizing the UAV potential through vehicle routing optimization. Applied Energy. 2019;242: 1164-1175. DOI: 10.1016/j.apenergy.2019.03.117

[43] The Government of the Republic of Serbia. Pravilnik o bespilotnim vazduhoplovima. Službeni Glasnik Republike Srbije. 2020; 108/15. Serbian.

[44] Vidović K, Šoštarić M, Budimir D. An overview of indicators and indices used for urban mobility assessment. Promet - Traffic\&Transportation. 2019;31(6): 703-714. DOI: $10.7307 /$ ptt.v31i6.3281

[45] Demir E, Bektas T, Laporte G. A review of recent research on green road freight transportation. European Journal of Operational Research. 2014;237(3): 775-793. DOI: 10.1016/j.ejor.2013.12.033

[46] Network for transport measures - NTM. Road cargo transport baselines $2018 \mathrm{EU} ; 2018$. Available from: https://www.transportmeasures.org/en/wiki/evaluation-transport-suppliers/road-transport-baselines-2017 [Accessed 30th August 2020]. 